\title{
EL LUGAR DEL NEOKANTISMO EN LA FILOSOFÍA MEXICANA
}

GUILLERMO HURTADO

INSTITUTO DE INVESTIGACIONES FILOSÓFICAS

UnIVERSIDAD NACIONAL AUTÓNOMA DE MÉxICO

El neokantismo fue una corriente que, si bien llegó algo tarde a México y fue vista con recelo por el grueso de la comunidad filosófica, desempeñó un papel de cierta relevancia en la vida filosófica mexicana durante varios años. Los neokantianos mexicanos protagonizaron, a partir de 1936 y hasta bien entrados los años sesenta, la reaccción más tenaz contra las doctrinas cultivadas por los filósofos mexicanos de más renombre en aquella época y, también, por sus colegas españoles exiliados. En contra de aquellas doctrinas (como el historicismo o el existencialismo), los neokantianos propugnaron por una filosofía científica y antimetafísica (coincidiendo, en algunos puntos, con las críticas que los marxistas y, más adelante, los analíticos hicieran a estas mismas doctrinas).

Narrar la historia del neokantismo en México requeriría un estudio de dimensiones que exceden las de este trabajo. El objetivo de este ensayo es más modesto: ubicar el movimiento neokantiano dentro del desarrollo de las ideas filosóficas en México y, en particular, y con más detalle, en el lapso que va de 1936 a 1939 . Fue en esos años que el neokantismo entró al escenario de la filosofía en México con la aparición de los primeros libros del más celebre de los neokantianos mexicanos, Francisco Larroyo, y, sobre todo, con las polémicas que entablaran los jóvenes neokantianos con dos de las figuras más importantes de la filosofía en México, Antonio Caso y José Gaos.

\section{Los precedentes del neokantismo en México}

El neokantismo fue una corriente que tuvo una influencia considerable en la filosofía alemana de finales del siglo xIx y principios del xx. Támbién la tuvo en algunos países de habla hispana. En Argentina, un grupo de filósofos, entre los que destacaba Alejandro Korn, suscribieron tesis afines a las del 
neokantismo y fundaron en 1929 la Sociedad Kantiana de Buenos Aires. ${ }^{1}$ La influencia del neokantismo en España también fue importante. Un grupo de intelectuales españoles -entre ellos Ortega y García Morente- estudiaron en Marburgo y recibieron la influencia de Hermann Cohen y Paul Natorp. Ahora bien, ¿por qué hubo un impacto del neokantismo en Argentina y en España a principios del siglo xx y no en México? A mí me parece que la causa principal de este fenómeno es la gran distancia filosófica que hubo entre México y Alemania hasta los años treinta del siglo xx. Sin embargo hay quienes piensan no sólo que tal distancia no existió, sino que hubo un impacto significativo de la filosofía alemana, y en particular kantiana, en México.

En un importante ensayo titulado "El neokantismo ante la tradición filosófica mexicana", 2 Juan Hernández Luna sòstuvo que desde mediados del siglo xix hubo en México una genuina tradición kantiana. Hernández Luna afirma que esto puede advertirse si examinamos la polémica entre los defensores del positivismo y los de la filosofía idealista alemana que giró en torno a la cuestión de si la Lógica o ciencia del conocimiento del krausista G. Tiberghien debía sustituir a la Lógica positivista de Alejandro Bain como libro de texto obligatorio de la materia de lógica en la Escuela Nacional Preparatoria. La defensa del krausismo se hizo desde el periódico La República dirigido por Ignacio Manuel Altamirano (que ya en aquel entonces, según cuenta Hernández Luna, exponía las filosofías de Kant, Fichte, Schelling y Hegel en su cátedra de Historia de Filosofía de la Escuela de Jurisprudencia) y la del positivismo desde La Libertad, dirigido por Justo Sierra. Hernández Luna también recordaba que el oponente más insigne de los positivistas mexicanos en aquellos años, José María Vigil, se apoyó en la filosofía de Kant para formular algunas de las críticas que lanzaba desde la Revista Filosófica y que, años más tarde, los miembros del Ateneo de la Juventud también habían enarbolado la doctrina de Kant en contra del positivismo.

Hernández Luna sostiene con base en lo anterior que podemos hablar de una tradición kantiana mexicana desde mediados del siglo xIx, ya que los pensadores mexicanos de aquella época utilizaron ideas de raigambre kantiana en sus discusiones sobre cuestiones relacionadas con la cultura, la educaciór y la política nacional. Esta tesis se asemeja a la interpretación del positivismo en México hecha por Leopoldo Zea (y de hecho, sería su contraparte, ya que al positivismo mexicano de los científicos se opondría

1 Sobre la filosofía y la figura de Alejandro Korn, véase Francisco Romero, et al. (comps.), Alejandro Korn, Losada, Buenos Aires, 1940.

2 Juan Hernández Luna, "El neokantismo ante la tradición filosófica mexicana", Filosofía y Letras, no. 32, octubre-diciembre, 1948. 
el kantismo mexicano de los viejos liberales). ${ }^{3}$ La interpretación de Zea puede cuestionarse, pero me parece que aunque aceptáramos que sí hubo un positivismo mexicano, es claro que hubo suficientes diferencias entre el supuesto kantismo mexicano y el movimiento positivista, para que dudemos de que haya habido una tradición kantiana mexicana.

Me parece que Hernández Luna comete el error de describir como kantianos a los defensores de cualquier filosofía idealista poskantiana. Los krausistas mexicanos, por ejemplo, pertenecían a una tendencia idealista -que en sentido estricto ni siquiera era germana, sino francófona, puesto que Tiberghien era belga - pero no a una kantiana. $Y$ en realidad sus afinidades estaban más por el lado del espiritualismo francés y de la defensa de la metafísica que de la tradición kantiana que recogieron los neokantianos. ${ }^{4}$ Por otra parte, los supuestos kantianos mexicanos -y esto lo reconoce Hernández Luna - conocían la filosofía de Kant sólo a través de fuentes indirectas - por ejemplo, los manuales de Victor Cousin. ${ }^{5}$ Los positivistas mexicanos, en cambio, partieron de una lectura cuidadosa de fuentes directas, e incluso de un contacto personal con sus autores y la compenetración que tenían con los temas y las discusiones de la escuela positivista no puede compararse con la que sus oponentes tenían del idealismo germano y, en particular, del idealismo kantiano. Por último, no es gratuito recordar que fueron los positivistas los que ganaron la partida: los textos en los que se educaron varias generaciones de preparatorianos fueron de clara orientación positivista y, eventualmente, ésta fue la filosofía favorecida por el régimen. Además, si bien los ateneístas sostuvieron que el positivismo podía atacarse desde un flanco kantiano, no fue este flanco el que tuvo más importancia en su batalla en contra del positivismo. Como veremos, fueron otras filosofías las que tuvieron impacto en ellos. De aquí que la crítica de los ateneístas al positivismo no sea una mera continuación de la de Vigil o Altamirano. Los ateneístas no sólo no se inspiraron en el krausismo, sino que les parecía que esta doctrina era -en palabras de Vasconcelos- "no sólo mediocre, también inmoral, en el sentido clásico de falta de fuerza y decisión ante la responsabilidad" (Ulises criollo, Obras completas, vol. I, Libreros Mexicanos Unidos, p. 580). Por lo tanto, pienso que es una exageración hablar de una tradición kantiana mexicana previa al surgimiento de la corriente neokantiana hacia 1936.

3 Véase Leopoldo Zea, El positivismo en México, Fondo de Cultura Económica, México, 1943.

4 Sobre las influencias filosóficas de Vigil y los demás contrincantes de los positivistas, véase, Charles Hale, La transformación del liberalismo en México a fines del siglo xix, Vuelta, 1991.

5 Esto último lo menciona Ramos en su Historia de la filosofía en México, Imprenta Universitaria, México, 1943, p. 113. 
La realidad es que los filósofos mexicanos de finales del siglo xix y principios del xx estaban poco enterados de qué sucedía en Alemania y no manejaban con presteza los conceptos de la filosofía alemana poskantiana. La comparación con sus coetáneos españoles es reveladora. Aunque en el reporte que hiciera el filósofo polaco W. Lutoslaswski sobre el kantismo en España en 1897 afirmaba no haber encontrado un solo filósofo español que conociera a fondo la obra de Kant, para esa fecha ya Sanz del Río había realizado el primer viaje de estudios de un español a Alemania -buscando las ideas con las que pudiera renovar el paisaje intelectual de la penínsulaseguido por el cubano José del Perojo, alumno de Kuno Fisher y primer traductor de parte de la Crítica de la razón pura. ${ }^{6}$ Pero la diferencia, la gran diferencia, la marca Ortega y su generación. Cuando en la primera década del siglo xx, los jóvenes Ortega y García Morente recorrían las calles de Marburgo con sus libros en alemán bajo el brazo, en México, los jóvenes integrantes del Ateneo de la Juventud apenas libraban una lucha - junto con Justo Sierra- contra el veto positivista a la educación filosófica clásica. Y tampoco hay que olvidar que los ateneístas fueron, en buena medida, autodidactos por lo que se refiere a la filosofía y que los autores que tomaron como guía para escapar de la rígida prisión positivista fueron, principalmente, James, Boutroux y Bergson. ${ }^{7}$ Sin embargo, los ateneístas leyeron a Kant y a otros autores alemanes como Schopenhauer y Nietzsche. En su ensayo "Kant en Argentina y México" (que es el capítulo VII de su libro México, apuntamientos de cultura patria, Imprenta Universitaria, México, 1943), Caso cuenta que se reunía con Pedro Henríquez Ureña, José Vasconcelos, Alfonso Reyes y Martín Luis Guzmán para leer y comentar la traducción de José del Perojo de la Estética y de la Analítica trascendental (que estaba precedida de una vida de Kant y una historia de la filosofía crítica escritas por Kuno Fischer). La lectura de Kant, cuenta Caso en 1943, liberó a los ateneístas del empirismo. Pero aunque la lectura de Kant haya resultado ilustrativa a los ateneístas, hubo otras, no menos influyentes, por ejemplo, la obra de Boutroux sobre la contingencia de las leyes naturales expuesta y comentada por Caso (y que tuvo el efecto, según Vasconcelos, de destruir

6 Sobre el reporte de Lutoslawski y la tradución de José del Perojo, véase, Francisco Romero, Ortega y Gasset y el problema de la jefatura espiritual y otros ensayos, Losada, Buenos Aires, 1960.

$7 \mathrm{El}$ interés de los ateneístas en la filosofía francesa llegó a oídos de algunos intelectuales parisinos que vieron en ello - con autocomplacencia característica- un signo alentador del progreso espiritual de América. Cuando Alfonso Reyes le comentó a Bergson cómo su filosofía era estudiada en un país asolado por una revolución, Bergson, viendo el lado bueno del asunto, le dijo que era "un testimonio no poco consolador sobre las posibilidades del espíritu ante las fuerzas oscuras del desorden" (Alfonso Reyes, "Pasado inmediato", en Obras completas, vol. XII, p. 215). 
toda la labor positivista de los anteriores treinta años (op. cit., p. 507). Además como el propio Caso añade en su ensayo, muy pronto sus lecturas tomaron otras rutas y fue así como dejaron a Kant para tomar a Nietzsche $\mathrm{y}$, sobre todo, a Bergson. El entusiasmo por Bergson -y, en particular, por L' évolution créatrice - llegó al grado de que en una célebre conferencia pronunciada en 1910, José Vasconcelos declarara que el bergsonismo era la filosofía de la juventud pensante mexicana. ${ }^{8}$

Otro dato que hay que tener en cuenta es que los renovadores de los estudios filosóficos en México no leían alemán. (Cuando Caso se interesó en la filosofía de Husserl a principios de los años treinta lo hizo a partir de traducciones españolas y francesas.) Los primeros filósofos mexicanos que manejan el alemán y van a estudiar a Alemania pertenecen a la generación de los nacidos en la primera década del siglo xx. Entre ellos, destacan Francisco Larroyo, que estudió en Alemania entre 1931 y 1933 y tradujo a Windelban y a Natorp, y Eduardo García Máynez - figura clave de la filosofía mexicana del siglo xx- que estudió en Berlín con Hartmann y en Viena con Alfred Verdroșs. Las diferencias entre los filósofos de esta generación y los del Ateneo de la Juventud son importantes. Mientras que la generación del Ateneo había tomado la filosofía francesa como modelo, los de la generación del treinta adoptaron, por lo general, la filosofía alemana y pensaban que la filosofía había de ser una disciplina más cercana a la ciencia que al ensayo. ${ }^{9}$

Se ha dicho que el interés por la filosofía alemana en México - así como en el resto de América Latina- lo fomentó la difusión que Ortega hiciera de ella en Revista de Occidente y en su editorial homónima. El mismo Larroyo afirmaba, en un ensayo publicado en 1949, que uno de los dos hechos que influyeron de manera significativa en la aparición del neokantismo en México había sido la tarea de difusión hecha por Ortega y Gasset en la Revista de Occidente (el otro hecho significativo había sido la cátedra de Caso). ${ }^{10}$ Pero si bien la influencia de la Revista de Occidente fue muy grande, pienso que no todo lo que sucedió se debió a ella. En el caso del neokantismo, por ejemplo, parece que las rutas de entrada fueron otras. El filósofo más promovido por la revista fue Scheler — se le tradujeron seis libros seguido por Husserl- en 1929 se traducen las Investigaciones lógicas. Del neokantiano

8 José Vasconcelos, "Don Gabino Barreda y las ideas contemporáneas", en A. Caso, et al., Conferencias del Ateneo de la Juventud, unam, México, 1984.

9 Una excepción notable por lo que respecta a esta característica común de los miembros de la generación de filósofos mexicanos nacidos alrededor de 1910 es la figura de Antonio Gómez Robledo, que desarrolló con profundidad y brillantez su humanismo cristiano por otras vertientes.

10 Véase Larroyo, "Pensamiento y obra del idealismo crítico en México", Filosofía y Letras, no. 36, 1949, p. 203. 
Natorp publicaron, en 1925, un librito sobre Platón. Pero de neokantismo en sentido estricto, nada. Y es que incluso podría afirmarse que la Revista de Occidente fue antineokantiana. Recordemos que en 1924, Ortega publicó en ella su célebre ensayo "Kant, reflexiones de centenario" en donde después de contar cómo había escapado de la "prisión kantiana", acusaba a los kantianos recalcitrantes de ser "la mayor rémora para el progreso" y "los únicos reaccionarios que verdaderamente estorban" (p. 2). Y Ortega hablaba por un grupo de intelectuales, liderados por él, que habían dejado atrás el entusiasmo por el neokantismo que habían compartido en la primera década del siglo $x x .{ }^{11}$ Por lo tanto, si hubo alguna influencia española en el neokantismo mexicano --lo que parece poco probable - ésta debió haber sido transmitida mediante publicaciones previas. ${ }^{12}$ No se puede descartar la hipótesis de que haya llegado alguna influencia neokantiana desde el sur del continente, pero no tengo datos para sostenerla. ${ }^{13}$

Si bien la Revista de Occidente dio a conocer en México la nueva filosofía alemana, el interés académico en ella se debe al hecho de que Caso - la figura más influyente de la filosofía en México en ese tiempo- se abrió a las corrientes alemanas y las difundió en las aulas. Habría que recordar que, de 1927 a 1933, Adalberto García de Mendoza había enseñado, desde su llegada de Alemania, la nueva filosofía germana —el neokantismo de Baden, Husserl, Scheler y Heidegger - pero fue Caso, con su grandísima influencia sobre la vida cultural mexicana, quien inclinó definitivamente la balanza. ${ }^{14}$ A partir de 1933 se empieza a notar en los libros de Caso la presencia de Husserl, Scheler, Hartmann y, por último, de Heidegger. Pero como señalara E. Salmerón, "estas nuevas lecturas no desviaron sino que

11 Ortega dice que "El grupo de jóvenes que entre 1907 y 1911 aprendía en la ciudadela del neokantismo los usos de la milicia filosófica, al liegar a los veintiséis años [... . ] no eran ya neokantianos" (p. 32). Y en ese mismo texto hace una afirmación más tajante: "Aquel grupo de jóvenes no había sido nunca, en rigor, neokantiano" (p. 42). Cfr. Ortega y Gasset, "Prólogo para alemanes", Obras completas, Revista de Occidente, Madrid, 1962, t. VIII.

12 Conviene recordar la traducción de la Pedagogía social de Natorp, publicada en 1913 con prólogo de García Morente, y la que hiciera María de Maeztu en 1914 del libro Religión y humanidad, también de Natorp. En "Pensamiento y obra del idealismo crítico en México", Larroyo recuerda la Pedagogía social de Natorp, pero afirma que había pasado inadvertido en los orígenes del movimiento neokantino en México (op. cit., p. 203).

13 Es posible que algunas publicaciones que llegaron a México desde Argentina pudieron haber tenido alguna influencia sobre Larroyo o Rodrígueź, por ejemplo, el trabajo de Rivarola ¿Ha leído Spencer a Kant? del año 1903 o algunos números de la Revista de Filosofía que publicaba Ingenieros.

14 De Adalberto García de Mendoza véase: La dirección racionalista ontológica en la epistemología, Talleres Gráficos de la Nación, México, 1928 y Lógica. Obra de Texto en la Escuela Nacional Preparatoria de México, t. I, Introducción, significaciones; t. II, esencias, juicio, concepto, Cultura, México, 1932. Sobre García de Mendoza véase, Hernández Luna, op. cit. y el libro de inminente aparición de la doctora Dulce María Granja, El neokantismo en México. 
ahondaron el cauce primero de su pensamiento y esto hizo que, a pesar de las lecturas comunes, la brecha que existía entre él y sus discípulos no se acortara". ${ }^{15} \mathrm{Y}$ es que las preocupaciones fundamentales de Caso y de los ateneístas no eran las de los neokantianos. Para los ateneístas, el positivismo había exaltado en exceso el papel de las ciencias en detrimento de la intuición, las esencias y los valores. Poco les importaba a ellos, a diferencia de los neokantianos, la justificación de las ciencias particulares o el problema del conocimiento. ${ }^{16}$ La renovación filosófica en México en la primera década del siglo xx se acercaba más al espiritualismo francés, a Boutroux, a Bergson que a Cohen o a Rickert. En otras palabras, la reacción mexicana al positivismo siguió muy de cerca la reacción francesa al positivismo (también francés). Es más, podría decirse que el desconocimiento del neokantismo en México hasta antes de la tercera década del siglo xx se explica por la enorme influencia de la filosofía francesa en la mexicana -influencia que comparten los ateneístas con sus maestros positivistas. $\mathrm{Y}$ es que aunque el neokantismo fue la filosofía predominante en la Alemania de finales del siglo xix y principios del xx, tuvo un impacto virtualmente nulo en la filosofía francesa, tanto así que ninguna, absolutamente ninguna, obra de Cohen o de Natorp fue traducida al francés. ${ }^{17}$

\section{Francisco Larroyo: neokantiano mexicano}

La historia de la filosofía es historia de las ideas, pero su trama transcurre por una urdimbre de personajes de toda suerte y talante. Hay personajes que, sin ser centrales, cumplen con un papel importante en algún momento de la narración. Podría decirse que en cada comunidad filosófica hay este

15 Fernando Salmerón, Cuestiones educativas y páginas sobre México, Universidad Veracruzana, Xalapa, 1980, p. 166.

16 No obstante, sería erróneo inferir que Caso y Vasconcelos eran enemigos a ultranza de todo lo científico. En la conferencia antes citada, Vasconcelos sostenía que los ateneístas no habían adoptado el bergsonismo arrastrados por la moda, sino que antes se habían asegurado de que dicha filosofía no estuviera en desacuerdo con las leyes científicas, ni infringiera las leyes de la lógica. Si renunciaron al positivismo, decía Vasconcelos, fue porque "el positivismo de Comte y Spencer nunca pudo contener nuestras aspiraciones; hoy que, por estar en desacuerdo con los datos de la ciencia misma, se halla sin vitalidad y sin razón parece que nos liberamos de un peso en la consciencia y que la vida se ha ampliado" (Vasconcelos, op. cit., p. 111). Este afán de ir de acuerdo con los resultados de la ciencia puede encontrarse a todo lo largo de la filosofía de Vasconcelos. Por ejemplo, al final de su Todología. Filosofía de la coordinación (Ediciones Botas, México, 1952), él sostenía que su sistema filosófico era "rigurosamente científico y experimental" (y también, sin que esto le pareciera contradictorio, "gloriosamente revelado").

17 Y como señala con estupor Philonenko, de quien tomo este dato, todavía en 1989 no se había traducido al francés un sólo libro de Cohen o Natorp, véase A. Philonenko, L' ecole de Marbourg, Librairie Philosophique J. Vrin, París, 1989. 
tipo de personajes secundarios y que, a menos que se haga un esfuerzo por recordarlos, sus nombres tienden a olvidarse. Francisco Larroyo es uno de estos personajes. Larroyo nació en 1912 y murió en 1981. En 1934, obtuvo la maestría en filosofía y en 1936 el doctorado en la misma disciplina, ambos títulos otorgados por la Universidad Nacional Autónoma de México. Desarrolló su labor docente en la Escuela Normal de Maestros, en donde impartió clases desde 1934, en la Escuela Nacional Preparatoria y, a partir de 1954, en la Facultad de Filosofía y Letras de la UNAM, de la que llegó a ser Director de 1958 a 1966. En 1937 fundó, junto con Guillermo Héctor Rodríguez, el "Círculo de amigos de la filosofía crítica" al que asistieron, entre otros, Edmundo Escobar, Juan Manuel Terán, Elí de Gortari y Miguel Bueno. ${ }^{18}$ El Círculo publicó algunos libros y una Gaceta filosófica de los neokantianos. Una historia completa del neokantismo en México debería ocuparse de examinar detalladamente la obra de cada uno de los integrantes de este Círculo, de las actividades del Círculo y de los contenidos de la Gaceta. Pero como aquí apenas examino, con algo de cuidado, el periodo de 1936-1939 y, en especial, la figura de Larroyo, paso de largo aquellas tareas. ${ }^{19}$

El neokantismo de Larroyo resultaba anacrónico para muchos de sus colegas, y es que Larroyo empezó a publicar cuando el neokantismo había perdido influencia en Alemania, España y Argentina. El primer libro de Larroyo, La filosofía de los valores, se publica en 1936 (por la Editorial Logos, México, D.F.) cuando las corrientes filosóficas en boga en hispanoamérica eran otras: la fenomenología de Husserl, el perspectivismo de Ortega, el

18 Para una lista completa de los integrantes del Círculo véase: Francisco Larroyo, "Pensamiento y obra del idealismo crítico en México", Filosofía y Letras, no. 36, 1949, p. 204.

19 Daré sólo algunos datos sobre Miguel Ángel Cevallos, Edmundo Escobar, Juan Manuel Terán, Fausto Vallado y Miguel Bueno (de Guillermo Héctor Rodríguez diré algo más adelante). Miguel Ángel Cevallos, coetáneo de Larroyo, publicó junto con él un texto de lógica para el bachillerato, pero más adelante se alejó de la corriente neokantiana. Edmundo Escobar fue coautor, con Larroyo, de libros sobre diversos temas desde la perspectiva neokantiana (uno de ellos: Sistema e historia de las doctrinas filosóficas, Porrúa, México, 1968) y escribió un libro sobre la trayectoria filosófica de su maestro: Francisco Larroyo y su personalismo crítico, Porrúa, México, 1970. Fausto Vallado escribió una introducción a la filosofía de orientación neokantiana (Propedéutica filosófica, Editorial José M. Cajica, Puebla-México, 1967) además de un par de libros sobre filosofía del derecho y diversos artículos. Juan Manuel Terán perteneció al Círculo neokantiano aunque luego se alejó de esta corriente. Es autor de un libro sobre La idea de la vida en el pensamiento español (Talleres Gráficos de la Nación, México, 1953), en donde hace una crítica del raciovitalismo español desde una postura neokantiana. Miguel Bueno también estuvo ligado en su juventud al Círculo neokantiano y escribió algunas obras en esa corriente -entre las que hay que destacar su primer libro, Reflexiones en torno a la filosofía de la cultura (Imprenta Universitaria, México, 1956). Bueno es autor de varias docenas de libros e inumerables artículos en los que ha desarrollado un sistema filosófico cuya base es la axiología. 
existencialismo de Heidegger. En ese mismo año, en Argentina, moría Alejandro Korn y Francisco Romero daba a conocer la fenomenología. ${ }^{20}$ En México, el neokantismo de Larroyo también llegaba a destiempo. El patriarca Antonio Caso había publicado en 1934 su libro La filosofía de Husserl. Samuel Ramos había publicado en ese mismo año El perfil del hombre y la cultura en México en donde se advierte ya la influencia del pensamiento de Ortega y se inicia un camino temático y metodológico que otros filósofos mexicanos habrían de seguir tiempo después. Además, García Máynez ya daba a conocer la filosofía de Hartmann y - como ya vimos- García de Mendoza había, incluso, enseñado la de Heidegger. Sin embargo, Larroyo asumió su neokantismo con plena conciencia de que no estaba de moda ni en Europa ni en México. Más aún, él consideraba que los que realmente eran anacrónicos eran sus opositores, a los que llamaba epígonos, por haber nacido depués de la época en la que tuvo vigencia su manera de pensar.

Los neokantianos mexicanos recibieron influencia de las dos escuelas más importantes de este movimiento: la de Marburgo y la de Baden. Los autores que más citaban en sus textos eran: Cohen, Natorp, Windelban y Rickert. Los neokantianos alemanes consideraban que la filosofía podía convertirse en ciencia rigurosa sólo si tomaba la ruta que había trazado Kant; había que rechazar ante todo las pretensiones especulativas de la metafísica precrítica, pero, a la vez, había que atacar al positivismo, al materialismo y al naturalismo que negaban a la filosofía un campo propio en el conocimiento. Sin embargo, las diferencias entre las escuelas de Marburgo y de Baden son significativas. Mientras que la primera se orientó, primordialmente, a la fundamentación de las ciencias naturales, la segunda dirigió su atención a la cultura, la historia y la religión. Para la primera, la realidad puede verse como un enlace lógico de conceptos puros -el llamado panlogismo. Para la segunda, en cambio, el fundamento del ser lo constituyen los valores. Las dos vertientes del neokantismo fueron cultivadas en México, aunque quizá fue la de Baden la que tuvo mayor impacto, incluso fuera del grupo de los neokantianos, por su énfasis en la axiología. ${ }^{21}$

20 Hacia 1937, el neokantismo ya era visto en Argentina como cosa del pasado. Esto se puede comprobar si se examina la traducción (de García Morente) de Ciencia cultural y ciencia natural de Rickert que publicara Espasa Calpe de Argentina en 1937. La traducción va antecedida por un prólogo de Ortega en donde dice, en pocas palabras, que aunque el neokantismo de Rickert ya huele a rancio, todavía hay algo que aprender de él. Este prólogo va seguido de otro texto de Romero en donde se hace una presentación de la figura y la filosofía de Rickert al público argentino.

21 Para un estudio reciente sobre el neokantismo alemán véase: K.C. Köhnke, The Rise of Neo-Kantianismo; German Academic Philosophy between Idealism and Positivism, Cambridge, 1991. 
¿Se distingue el neokantismo mexicano del alemán? A mí me parece que por lo que respecta a la concepción de la filosofía e incluso a sus tesis fundamentales, no hay ninguna diferencia significativa; nada que nos permita decir que hay una corriente neokantiana mexicana. Los neokantianos mexicanos fueron más bien expositores de las ideas de los neokantianos alemanes. Pienso que el aspecto más interesante del neokantismo en México fueron las polémicas que hubo entre sus miembros y los representantes de otras filosofías. Como veremos, Larroyo fue un crítico tenaz de todas las corrientes filosóficas que llegaron a México a partir de los años treinta: la fenomenología, el perspectivismo, el existencialismo, el historicismo. Estas doctrinas fueron promovidas por el grueso de los profesores de la Facultad de Filosofía de la unam y por la mayoría de los filósofos españoles que se integraron a ella. Según Larroyo, las doctrinas que Caso, Ramos, García Máynez, Gaos, Xirau y los demás exiliados españoles propagaban entre sus discípulos pertenecían a un momento regresivo de la filosofía europea. Y dedicó buena parte de sus esfuerzos a atacar con vehemencia estas ideas. Larroyo polemizó con Gaos en 1939, con Francisco Romero en 1941 -a propósito de su Filosofía de la persona - y con Joaquín Xirau en 1941.

Larroyo fue un autor muy prolífico. Publicó una treintena de libros, varios de ellos en colaboración con Edmundo Escobar. Pero a pesar de escribir sobre una gran cantidad de temas, tanto él como su grupo tuvieron un lugar marginal en la filosofía en México, tanto así que las obras de Larroyo son, hoy en día, difíciles de encontrar en librerías y raras veces son citadas. Esto se debe, en parte, a que — como ya dije - Larroyo enarboló lo que se veía en aquella época como un neokantismo trasnochado con el que atacaba a las corrientes filosóficas que estaban en el centro de la discusión y que eran defendidas por las figuras de más renombre. Es por ello que tanto el neokantismo como el neotomismo cobraron fama, en aquellos años, de movimientos reaccionarios. ${ }^{22}$

Pienso que otra de las causas de la marginación de los neokantianos mexicanos es que muy pronto cobraron fama de agresivos y polemistas. Con estos adjetivos los califica Leopoldo Zea en La filosofía en México (Editorial Libro Mex, 1955). Si bien Zea reconoce que la crítica siempre es saludable para la labor filosófica, afirma que a los neokantianos se les pasa la mano y, en especial, a los más jóvenes en los que "el tecnicismo, la terminología, el puro juego lógico de los términos utilizados para polemizar deslumbran

22 Un caso aparte - del que no me ocuparé aquí- es el de la influencia de Larroyo y de la pedagogía social del neokantismo en la orientación de la pedagogía mexicana. No hay que olvidar que durante la gestión de Larroyo como director de la Facultad de Filosofía y Letras de la UNAM se fundó la carrera de pedagogía. En El neokantismo en México, la doctora Dulce María Granja se ocupa de esta cuestión. 
y conducen hasta la pedantería" (p. 100). Otro reproche que se les hizo fue su supuesta desvinculación de la realidad, ya sea metafísica o nacional. Sobre la primera, dice Zea que en "casi todos los trabajos de esta Escuela la Lógica adquiere una categoría, casi mitológica, a expensas de la realidad, Lo Universal de la Lógica se impone a costa de lo humano" (p. 106). Como veremos más adelante, este tipo de crítica a los neokantianos tuvo mucho peso en un momento de la Filosofía en México en el que el interés por lo humano en general y, en especial, por lo mexicano, tuvo una gran importancia.

En lo que sigue examinaré dos libros de Larroyo publicados en la segunda mitad de la década de los treinta y la polémica que sostuvo con José Gaos en esa misma época. También voy a reseñar la polémica sobre el neokantismo que sostuvieron Caso y Guillermo Héctor Rodríguez en 1937 y un diálogo sobre el neokantismo y la filosofía americana que sustuvieron Juan Manuel Terán y Leopoldo Zea en 1947. Me parece que el estudio de estas polémicas es importante para conocer no sólo la manera en la que se argumentaba a favor o en contra de estas doctrinas, sino la manera en la que estas doctrinas obtenían posiciones en lo que podríamos llamar "la lucha por el poati intelectual". No me voy a ocupar del resto de la extensa obra de Larroyo o de las obras de otros neokantianos mexicanos por dos razones —además de la obvia de que ello requeriría, como ya dije, más páginas de las que tiene este trabajo. La primera, es que me parece que el verdadero momento protagónico del neokantismo mexicano sucedió en el periodo que voy a examinar: de 1936 a 1939. Éste fue el momento en el que sus críticas fueron escuchadas con mayor atención y tuvieron una respuesta de sus oponentes de mayor prestigio. Después de este periodo, aunque el combate de los neokantianos haya seguido, aunque hayan escrito más y más libros, sus oponentes ya no respondieron directamente a sus críticas —que, para ser justos, casi siempre seguían siendo las mismas-y construyeron alrededor de ellos una especie de muro de silencio, que todavía persiste hoy en día -transformado en muro de olvido. Sin ęmbargo, el muro fue roto en unas cuantas ocasiones —. -g., por Hernández Luna y por Salmerón- para hacer críticas del neokantismo; y de estas críticas me ocuparé más adelante. La segunda razón por la que presto atención especial a este periodo, se refiere al personaje central de nuestra narración, y es que soy de la opinión de que casi todo lo que Larroyo escribió después —que fue mucho, y que incluso pretendió la formulación de un sistema filosófico original, el personalismo crítico- tiene poco que añadir en su dirección filosófica general, en su fundamento argumentativo y en su estilo retórico a lo que escribió en los primeros años de su producción. Más adelante daré las razones por las que pienso esto. 


\section{La filosofía de los valores}

La filosofía de los valores -dedicado a Antonio Caso- es una enfática defensa de la filosofía crítica frente a los embates de doctrinas que en aquel tiempo estaban en boga. En la Introducción, el joven Larroyo - tenía apenas 26 años - advierte al lector que en ciertos sectores se supone que la filosofía crítica está superada y ofrece, como ejemplo, una cita de Ortega en la que éste afirma que el método crítico es "como toda la ideología del siglo xx, una cosa tosca, maniática, imprecisa, inelegante y sin remedio periclitada" (p. 15). Los seguidores de Ortega, dice Larroyo, piensan que "la tradición del criticismo alemán está en bancarrota, y mientras festejan los éxitos literarios de Spengler, etc., se les señala a los últimos neokantianos el camino de la conversión". La exigencia en los libros y en la cátedra, dice Larroyo, es la de ofrecer nuevos hechos y nuevas ideas. Pero Larroyo no abjura del neokantismo. En contra de lo que sostenía Ortega, Larroyo creía que era imposible renunciar a los avances del siglo xIx. Los resultados del siglo xx, nos dice, son un desarrollo de los del xix. El problema, pensaba Larroyo, es que en el xx se habían olvidado las lecciones de la filosofía crítica y que esto había producido lo que él consideraba un momento regresivo de la filosofía, ejemplificado, entre otras maneras, por la dirección de las diversas corrientes que pretendían cultivar de nuevo los problemas metafísicos desacreditados por Kant.

Larroyo habla con respeto de la obra de Husserl, pero no así de la de los demás fenomenólogos, que considera se han desviado del camino trazado por el maestro. Acerca de la fenomenología dice:

Sobre esta novedad filosófica existe por dondequiera una rara incomprensión. Diletantes de todo linaje de continuo la invocan para describir su snobismo refinado y para muchas gentes ajenas a los círculos profesionales, pasa el nuevo método por ser una especie de intuición mágica y prodigiosa en la captación de ciertas verdades, asequibles, por lo demás, sólo a raras individualidades. (p. 67)

Larroyo dedica varias páginas a exponer lo que él considera el método fenomenológico genuino. No me ocuparé aquí de la cuestión de si la explicación del método fenomenológico ofrecida por Larroyo es correcta, pero sí de las críticas que le hace a Husserl. Larroyo tiene dos objeciones a la fenomenología que repetiría al pie de la letra en sus escritos posteriores (véase, por ejemplo, La lógica de las ciencias, 20a. ed., Porrúa, México, 1979, pp. 295$300)$. La primera, basada en una crítica que le hiciera Natorp a Husserl, ${ }^{23}$ es

23 Véase Investigaciones lógicas, V, cap. $1, \S 8$, en donde Husserl hace referencia a esta polémica. 
sostener que ya que el yo puro no puede ser objeto de intuición del mismo yo, el método fenomenológico es insostenible puesto que éste se funda en la posibilidad del análisis de la conciencia (p. 83). Si hubiera una intuición del yo, dice Larroyo, caeríamos en una regresión infinita, pues la reflexión de la reflexión habría de ser objeto de una nueva reflexión. La segunda objeción va dirigida a la tesis de que la evidencia apodíctica es un criterio de verdad. Larroyo sostiene que si la evidencia apodíctica misma cae - como lo afirma Husserl - bajo la consideración fenomenológica, se entra de nuevo en un círculo, pues la fundamentación de la evidencia apodíctica como un criterio de verdad supondría en su fundamentación fenomenológica esta misma evidencia (p. 85). Estas objeciones son de cierta consideración, pero, en mi opinión, no son definitivas para descartar de una buena vez, como lo hizo Larroyo, el método fenomenológico.

Larroyo afirma que Husserl está más cerca de Descartes que de Kant y que éste es, a fin de cuentas, su pecado. Es revelador que Larroyo haya señalado que Caso también opinaba que la fenomenología era un sistema cartesiano, más cercano a las construcciones del siglo xvı que a las de la filosofía poskantiana. La referencia a Caso puede tener el propósito de cortar cualquier sospecha de que entre aquellos fenomenólogos diletantes que ridiculizaba Larroyo se encontrara Caso. Y es posible que ésta fuera una de las muchas razones que pudo haber tenido Larroyo para dedicar el libro a su maestro (incluso dedica una sección entera de su libro al examen de sus ideas sobre el valor). Hay que recordar que algunos años atrás, en una de las polémicas más agrias de la filosofía en México, Samuel Ramos había criticado a Caso, su antiguo maestro y protector, acusándolo de ser un mero divulgador de las ideas filosóficas de moda.

Volviendo a La filosofía de los valores, Larroyo dedica el capítulo segundo de su libro a lo que él llama interpretaciones acríticas sobre la esencia de los valores. Larroyo distingue tres vertientes del acriticismo: el metafisicismo, el psicologismo y el sociologismo axiológicos. Entre los metafisicistas, Larroyo incluye a Scheler, Hartmann y a Ortega. A cada uno de ellos dedica un apartado. Larroyo describe el perspectivismo de Ortega como la doctrina que declara que no tenemos un conocimiento absoluto del mundo y que toda interpretación de la realidad está hecha inevitablemente desde una perspectiva particular y, en cierto modo, arbitraria. Larroyo no ofrece argumentos en contra del perspectivismo. Se limita a afirmar que esta doctrina puede caer en un relativismo inaceptable, aunque reconoce que Ortega evitaba esta derivación. Larroyo se ocupa del artículo de Ortega “¿Qué son los valores?" publicado en la Revista de Occidente de octubre de 1923. En dicho ensayo, Ortega sostenía que los valores son cualidades irreales que, sin embargo 
residen en las cosas. ${ }^{24}$ Larroyo estaba bien enterado de lo que sucedía en la filosofía española. En ese mismo capítulo, cita un trabajo de García Morente, "Ensayo sobre el progreso", publicado en la Revista de Occidente de enero de 1932, en donde éste se ocupa del tema de los valores y se declara seguidor de Ortega. Larroyo no deja de pasar la ocasión para lamentar que García Morente haya emigrado de la filosofía crítica para pasarse al bando de los fenomenólogos.

Pero veamos cuál es la postura de Larroyo con respecto a la esencia del valor, ya que esto nos permitirá también entender la concepción de la filosofía que él tenía y su filiación dentro de la corriente neokantiana. El valor, para Larroyo, es objetivo, pero no es, como pensaba Max Scheler, una verdadera cualidad de los objetos, ni tampoco es, como pensaba Ortega una cualidad irreal. El valor, dice Larroyo, es una dimensión relacionante de la conciencia, una legalidad auténtica, una forma de enlace a priori (p. 108). Ahora bien, la filosofía, afirma Larroyo, no puede ser más que filosofía de los valores. La filosofía, nos dice, es una ciencia rigurosa que indaga los modos de conciencia puros. Y si por cultura entendemos los productos, científicos o no, en que se conoce, se siente y se actúa en el mundo, la filosofía estudia los supuestos supremos de la cultura. Pero indagar las condiciones de la cultura, continúa Larroyo, es lo mismo que estudiar la actividad valiosa de la vida, es decir los valores y sus leyes. Por tanto, la filosofía es filosofía de la cultura, teoría de los valores (p. 193). Esta concepción de la filosofía es muy afín a la de Windelban, por lo que podríamos decir que el neokantismo de Larroyo en La filosofía de los valores es cercano al de la Escuela de Baden. La concepción de la filosofía como ciencia del valor, i.e., como axiología, tuvo en México a otros defensores, aunque la axiología que cultivaron no fue, como la de Larroyo, trascendental, sino más bien metafísica. Tal es el caso de Eduardo García Máynez, de Robert S. Hartmann y de Miguel Bueno, todos ellos, en algún momento, miembros del Instituto de Investigaciones Filosóficas de la UNAM.

\section{La polémica Caso-Rodríguez}

En una narración en la que el protagonista es un personaje secundario hay, a su vez, personajes secundarios. Guillermo Héctor Rodríguez, miembro fundador del Círculo de amigos de la filosofía crítica, es recordado en la historia de la filosofía en México por haber sostenido en 1937 una polémica con Caso acerca del neokantismo. Rodríguez fue desde joven un seguidor de

24 Riziere Frondizi sostuvo que este ensayo de Ortega fue el punto de partida de la concepción objetivista y absoluta del valor en el mundo de habla hispana (cfr. Tzivi Medin, Ortega y Gasset y la cultura hispanoamericana, Fondo de Cultura Económica, México, 1994, p. 70). 
la Escuela de Marburgo. La tesis con la que obtuvo la licenciatura en Derecho ya se inscribía en dicha corriente. Rodríguez fue difusor del neokantismo en la Facultades de Filosofía y Letras y de Derecho de la UNAM, sobre todo en ésta última, en donde dirigió por muchos años un grupo de estudio al que asistieron varios jóvenes que se convertirían en juristas de renombre. ${ }^{25}$

Según se cuenta, la polémica empezó a gestarse en los pasillos de la Facultad de Filosofía y Letras, al inicio del año lectivo 1937. Caso impartía la asignatura de "Filosofía de la historia" y Rodríguez la de "Epistemología y problemas selectos de lógica formal". "Por los cuchicheos y rumores que los alumnos de ambos maestros producían a la salida de clase - comenta Hernández Luna-Caso llegó a enterarse de las críticas que Rodríguez hacía a la metafísica y a la intuición, y por ellos mismos Rodríguez tuvo conocimiento de las objeciones que Caso formulaba a la filosofía de la Escuela de Marburgo." 26 Caso dio el primer paso. El 14 de abril de 1937 publicó en el El Universal un artículo intitulado "Por qué no somos kantianos". Como ningún neokantino aceptó el duelo, Caso volvió a insistir el 7 de mayo con el artículo "Kant y los panlogistas de Marburgo". Diez días después Rodríguez contestó en un artículo intitulado "La filosofía científica neokantiana y el valor de la metafísica y de la intuición". "La polémica entre Caso y Rodríguez se prolongó durante tres meses hasta que el editor de El Universal tuvo el tino de negarse a seguir publicando más artículos sobre el tema.

En "Por qué no somos kantianos" Caso dice que él no es kantiano porque piensa - a diferencia de Kant - que la metafísica se ocupa de las esencias, que éstas se dan en la intuición, son universales y no dependen de la conciencia. En este ensayo Caso afirma que quien, como los neokantianos de Marburgo, "niega al hombre la intuición de las esencias, desconoce la esencia de lo humano" (p. 607) y además rebaja su sabiduría y dignidad. No es extraño que este artículo no haya suscitado la reacción de Rodríguez puesto que la carga de la prueba estaba enteramente del lado de Caso. Esto cambia en "Kant y los panlogistas de Marburgo" en donde Caso hizo varias objeciones al neokantismo de Marburgo que luego repetiría en los demás artículos de la polémica. La primera objeción es que el neokantismo comete una falacia de ignorar la cuestión porque al preguntar por el ser de las cosas, responde inquiriendo por aquello que hace posible el conocimiento científico. La segunda objeción es que al declarar que la metafísica ha de sustituirse por una teoría del conocimiento, no hace más que adoptar otra

25 Rodríguez escribió los siguientes libros: El ideal de justicia y nuestro derecho positivo (1934); El metafisicismo de Kelsen (1947) y Ética y jurisprudencia (1947). Entre sus discípulos podemos contar a Juan Manuel Terán, Fausto Vallado y Ulises Schmill.

26 Juan Hernández Luna, "Prólogo a la polémica sobre el neokantismo", en A. Caso, Obras completas, I. Polémicas, UNAM, México, 1971, p. 599. 
metafísica que hace de cada ser un concepto. La tercera es que la filosofía irracionalista de su tiempo mostraba que la tesis panlogista de que el universo es cognoscible en sí no podía sostenerse ya que, en palabras de Caso, "no se encuentra en el universo una sola porción que sea completamente racional" (p. 611). La cuarta objeción es que la negación neokantiana de la intuición va en contra de "la conciencia intelectual de nuestro tiempo" (p. 612), es decir, la de Bergson, Husserl y Scheler. Detrás de la tercera y la cuarta objeciones se encuentra la afirmación de que el neokantismo es una filosofía superada. Caso llama al neokantismo con cierto desdén: "la filosofía de la Alemania anterior a la guerra" (p. 609).

A la objeción de que el neokantismo cae en una falacia de ignorar la cuestión, Rodríguez responde acertadamente, en mi opinión, que no ignora la pregunta por el ser, sino que la considera como carente de sentido y, por tanto, la sustituye por la pregunta por las condiciones de posibilidad del conocimiento. A menos que Caso muestre que la pregunta por el ser tiene el sentido que le niega el neokantiano —añade Rodríguez-su objeción está basada en una petición de principio. A la segunda objeción de Caso, la de que el neokantismo es una metafísica a pesar de lo que pregona, Rodríguez responde a Caso que cae en una contradicción puesto que en su artículo había afirmado que el criterio inmanentista de verdad de los neokantianos implica la negación de toda metafísica. Esta respuesta es poco afortunada puesto que lo que Caso quería decir — como aclara en su contrarrespuestaes que el criterio inmanentista implica la negación de toda metafísica realista. Sin embargo, a mí me parece que la segunda objeción -que es una objeción que se le hace comúnmente al neokantismo- no es tan fuerte como podría suponerse. El neokantiano puede cederle a Caso que propone cierto tipo de metafísica siempre y cuando su rechazo de la metafísica precrítica siga en pie. A la tercera objeción de Caso, la de que el irracionalismo es una "alta torre" que se levanta frente al neokantismo, Rodríguez responde que lo indeterminable no puede ser aceptado por la ciencia y menos aún ser su fundamento. Sin embargo, me parece que, tal como plantea su objeción, es Caso quien tiene la carga de la prueba de la tesis de que no todo lo real es determinable por la razón. A la cuarta objeción de Caso, la de que la filosofía contemporánea de su tiempo estaba basada en la aceptación de la intuición, Rodríguez responde que la intuición de esencias defendida por la fenomenología es inaceptable puesto que lleva a conclusiones absurdas. $Y$ en este punto, repite los argumentos que Larroyo había ofrecido en $L a$ filosofía de los valores contra la fenomenología. Es curioso que Rodríguez no hiciera ninguna referencia a Larroyo al utilizar los argumentos que él ya había publicado tres años atrás. No obstante, no dudo que Rodríguez haya discutido con Larroyo su respuesta a Caso y que los dos fueran conscientes 
de que la mejor manera en la que podrían combatir a sus poderosos contrincantes filosóficos era uniendo sus fuerzas (recordemos que en ese mismo año se funda el "Círculo de amigos de la filosofía crítica").

No voy continuar analizando los demás artículos de esta polémica. Me voy a limitar a dar mi opinión sobre ella. En su prólogo a la polémica, que aparece en el primer volumen de las Obras completas de Caso, Juan Hernández Luna afirma que ésta fue muy desigual. "Desde los primeros artículos fue notoria la superioridad del maestro Caso frente a su discípulo. [...] Puede decirse que su adversario no dio a Caso muchos dolores de cabeza, no le exigió pesadas faenas mentales" (p. 602). Coincido con Hernández Luna en que Rodríguez no le exigió mucho a Caso, pero esto no implica, como él sostiene, que Caso haya sido "notoriamente superior" a Rodríguez en la polémica. A mi parecer, por el contrario, que las objeciones de Caso al neokantismo están apenas esbozadas y que en no pocas ocasiones son, en realidad, tesis contrarias disfrazadas de objeciones. En estas últimas, es Caso quien, en rigor, lleva la carga de la prueba, pero en vez de ofrecer argumentos propios para sustentarlas, se apoya en la autoridad de terceros. Por otra parte, Rodríguez no tiene mejores dotes dialécticas que Caso y, por lo general, no demuestra ser un filósofo con muchos recursos. En resumen, la polémica entre Caso y Rodríguez no tiene gran valor filosófico, pero sí nos hace ver el nivel de información que tenían los filosófos mexicanos sobre las corrientes filosóficas de moda en Europa en ese momento y, también, la manera en la que el neokantismo se encontraba en una situación algo precaria en el juego de poder de la filosofía mexicana. ${ }^{27}$

\section{La polémica Larroyo-Gaos}

La Casa de España en México organizó en octubre de 1938 un ciclo de seis conferencias sobre el tema de la filosofía de la filosofía impartidas por José Gaos. Poco después del fin de las conferencias Larroyo publicó un artículo en la revista Hoy llamado "La filosofía de la filosofía" en el que criticaba las ideas expresadas por Gaos en sus conferencias. Gaos respondió a Larroyo en una carta que fue publicada en la misma revista y el intercambio continuó con dos artículos más de Larroyo y una respuesta de Gaos. La polémica

27 En la polémica, Rodríguez se refiere a Caso con un respeto exagerado que linda con la ironía. Lo llama, por ejemplo, "mi querido y egregio maestro de la idea y de la vida ejemplar". Esta actitud de Rodríguez contrasta con una anécdota que alguna vez me contara el malogrado Javier Esquivel y que, aunque fuera falsa, da una idea de la fama de persona agresiva que se ganó Rodríguez. La anécdota es la siguiente: en una discusión filosófica en la que alguien defendía una tesis contraria a la suya, Rodríguez desenfundó su pistola, la puso de un golpe sobre la mesa, y dijo algo así como: "así estoy más cómodo, ahora sí ya podemos seguir hablando..." 
fue publicada, junto con dos ensayos de ambos autores en donde exponen sus concepciones de la filosofía, en el libro Dos concepciones de la filosofía, publicado por La Casa de España a principios de 1940. Esta polémica es un documento importante no sólo para la historia del neokantismo en México sino de la recepción de los exiliados españoles en el medio académico mexicano. ${ }^{28}$

En el primero de sus artículos, Larroyo sostiene que no puede existir una disciplina que merezca el nombre de filosofía de la filosofía. La reflexión filosófica sobre la filosofía pertenece a la filosofía misma, no a otra instancia. $Y$ es que si hubiera una filosofía de la filosofía tendría que haber una filosofía de la filosofía de la filosofía y así hasta el infinito. La filosofía es el campo más elevado de investigación. Larroyo concede que -como había dicho Gaos- "es consubstancial a la filosofía el preconizar de sí misma, el hablar de sí misma" (p. 15), pero considera que la descripción de lo que hayan opinado los filósofos sobre la filosofía pertenece a la historia de la filosofía y que es injustificado designarla con el rubro de filosofía de la filosofía. Larroyo pasa a considerar la tesis de Gaos - que sostendría décadas después en sus Confesiones profesionales - de que el filósofo es víctima de una curiosa soberbia satánica que toma a Dios como objeto de superación. Larroyo contesta que hay célebres contraejemplos históricos a esta afirmación tales como Sócrates o Tomás de Aquino. Ahora bien, Gaos había presentado sus conferencias en la forma de una confesión personal, "la confesión de esta vocación, de esta profesión, de esta decepción" (p. 23). Pero Gaos decía también que "esto no va a ser sólo confesión, sino que va también a ser cuento o historia de lo sucedido [...] a mi generación, [...] al hombre contemporáneo y [...] al hombre en general" (p. 25).

A esto objeta Larroyo lo siguiente:

La historia o cuento de las vivencias personales del profesor Gaos por semejantes o diferentes que se les considere con las de su generación, no deja de ser un análisis empírico de su conciencia a muchas leguas de distancia del método filosófico [...] no creemos que por el camino de la descripción psicológica pueda revelarse el concepto de la filosofía, ni que tal descripción merezca el nombre de filosofía de la filosofía. (p. 26)

Veamos cómo responde Gaos a estas objeciones. Con respecto a la primera de ellas, Gaos aclara que él no ve la filosofía de la filosofía como una disciplina superpuesta a la filosofía, por lo que no hay peligro de la regresión ad inifinitum que denuncia Larroyo. Esta respuesta de Gaos me parece que

28 Gaos no fue él unico filósofo del exilio español al que Larroyo lanzó sus dardos retóricos. Véase, por ejemplo, su libro El romanticismo filosófico. Observaciones a la Weltanschaung de J. Xirau, Editorial Logos. 
bloquea la objeción antepuesta por Larroyo. En relación con la distinción entre historia de la filosofía y filosofía de la filosofía, Gaos dice que la historia del concepto de la filosofía es "la Historia de la filosofía de la filosofía que tiene historia, como la filosofía toda" (p. 74). Me parece que esta respuesta de Gaos es poco convincente ya que, como le replica Larroyo, a la historia del concepto de filosofía podría llamársele historia de la filosofía o filosofía de la filosofía según los intereses de cada quien. Con respecto a que no todos los filósofos son o han sido soberbios, Gaos responde de una manera que hace que su tesis sobre la soberbia de los filósofos no pueda ser falsificada. Dice Gaos: "La documentación histórica contra la soberbia como esencia de la filosofía es la documentación de la máscara de la soberbia del soberbio 'débil'". Ante esto no hay nada más que decir. Lo que hace Gaos es cerrarse por completo a la posibilidad de encontrar contraejemplos a su tesis. Por último, Gaos responde a la objeción de que su confesión es mera psicología. Gaos empieza por acortar las distancias entre la psicología y la fenomenología de la soberbia:

La filosofía de la filosofía comprende una psicología del filósofo. Pero esta psicología, como toda psicología, no puede hacerse sino mediante conceptos que son objeto de fenomenología, así la fenomenología de la soberbia es indispensable a la psicología del filósofo en cuanto soberbio. Pero hay, además, una fenomenología de la filosofía y del filósofo. Esta fenomenología, como toda fenomenología, debe hacerse a base de casos ejemplares empíricos y puede hacerse a base de uno solo... (pp. 75-76)

Gaos explica que la fenomenología ha evolucionado de manera que preste atención a los fenómenos humanos en su circunstancialidad, tal como enseña Ortega en sus Meditaciones del Quijote y concluye que:

No hay inconciliabilidad entre una fenomenología de la filosofia y la definición de ésta como confesión personal. La fenomenología de la filosofía puede descubrir precisamente que la esencia de la filosofía es ser confesión personal. (p. 76)

La contrarrespuesta de Larroyo a esta última respuesta de Gaos llega al fondo de la polémica entre ambos. Larroyo le dice a Gaos que si bien la fenomenología ha evolucionado, esto no significa que lo haya hecho bien. Y luego afirma:

También comparto con el profesor Gaos que la confesión personal sea una esencia captable fenomenológicamente, pero de que la fenomenología pueda describir la esencia de confesión personal, no se sigue de ningún modo que la filosofía se caracterice con semejante esencia. Mientras el profesor Gaos no 
aduzca la prueba de que la filosofía no es una ciencia eidética (universal) que investiga la esencia y leyes de los valores, no tiene el derecho de definir la ciencia fundamental en este plano de romanticismo filosófico. (p. 97)

Hay varias cosas que señalar en esta cita. La primera es que Larroyo concede que puede haber fenomenología y no sólo psicología de la confesión, pero le devuelve la carga de la prueba a Gaos de que ésta sea la esencia de la filosofía. Ahora bien, es importante darse cuenta de que Larroyo también le exige a Gaos que le muestre que la filosofía no es, como Larroyo piensa, una ciencia eidética que investigue la esencia y leyes de los valores.

En la segunda carta de Gaos a Larroyo, aquél le hace notar que las diferencias entre ambos no son meramente terminológicas, como en algún momento le sugiere Larroyo, sino dos concepciones distintas de la filosofía. Larroyo y Gaos se ocupan de explicar estas concepciones en los dos últimos textos del libro. El ensayo de Larroyo expone su concepción de la filosofía como ciencia de los valores. El de Gaos, llamado "Filosofía, personalidad" es una defensa de una concepción de la filosofía que atiende a la realidad de la vida humana. Si la filosofía ha de ser ciencia de los valores, ha de serlo de los valores tomados, no como ideas abstractas, sino como aspectos de nuestra vida concreta. Gaos admite que el concepto de "nuestra vida" es el concepto central de la filosofía de Ortega, a quien denomina su maestro. Sin embargo, entre el orteguismo y la concepción que tenía Gaos de la filosofía hay un hueco que queda sin llenar en su ensayo.

¿Puede declararse un vencedor de esta polémica? Si ésta se ve como el enfrentamiento de dos concepciones distintas de la filosofía es muy difícil señalar a un vencedor. Pero antes de que la disputa llegara a la formulación de estas concepciones antagónicas, me parece que Larroyo sacó la mejor parte por un corto margen. Gaos volvería a defender su filosofía de la filosofía en otros textos, notablemente en sus Confesiones profesionales, y también volvería a ser criticada por otros filósofos mexicanos. ${ }^{29}$

\section{La lógica de las ciencias}

El mismo año de la polémica con Gaos, Larroyo publicó La lógica de las ciencias, que habría de ser, con el tiempo, su obra más conocida. En 1979 —dos años antes de la muerte de Larroyo— La lógica de las ciencias llegó a su vigésima edición actualizada con un tiraje de diez mil ejemplares. La causa

29 Larroyo no fue el único filósofo mexicano que criticó la concepción de Gaos acerca de la labor filosófica. Después de la muerte de Gaos, uno de sus discípulos más cercanos, Emilio Uranga, publicó una crítica despiadada de la visión que tenía Gaos sobre la filosofía como disciplina y como forma de vida (¿De quién es la filosofia?, Federación Editorial Mexicana, México, 1977). 
de semejante éxito comercial se debe a que el libro fue utilizado durante décadas como uno de los libros de texto para la materia de "Lógica" en el bachillerato nacional. ${ }^{30}$

En La lógica de las ciencias - dedicada a Hermann Cohen-Larroyo vuelve a defender su idea de la filosofía como ciencia de los valores. Pero el libro es un tratado de lógica entendida como la doctrina del pensamiento y más específicamente, como una metodología de la ciencias. La lógica, para Larroyo, comprende no sólo lo que hoy consideramos como tal, sino parte de lo que hoy incluiríamos dentro de la epistemología y la filosofía de la ciencia. Larroyo considera que lógica es una de las ramas analíticas de la filosofía y que ésta se ocupa del estudio del juicio y, en particular, de la ciencia, que es en donde mejor se ejemplifica el valor fundamental de este dominio de la cultura, que es la verdad.

La lógica no especula en el vacío; no fantasea en el mundo de la quimera; al contrario, hunde su planta en el territorio de la cultura llamada ciencia. Por tal motivo, los clásicos de la filosofía crítica han declarado con pulcritud que su materia de estudio reside en el factum de la ciencia, esto es, en los resultados de la investigación particular. Pero en un sentido profundo, la ciencia, como territorio cultural, nunca podrá considerarse algo definitivamente acabado y concluso; sus perspectivas de progreso son infinitas; lo que se traduce en una evolución siempre creciente de las formas del logos. Es falso de toda falsedad que Aristóteles haya creado la lógica en su forma perfecta. (p. 79) ${ }^{31}$

El libro se divide en dos partes. En la primera, denominada lógica analítica, se ocupa de las funciones lógicas fundamentales del razonamiento

30 La presencia de los neokantianos en la educación filosófica en el nivel medio fue significativa. Como decía Fernando Salmerón en 1975: "A juzgar por el número de obras destinadas a usos escolares -y el número correspondiente de ediciones-, puede decirse que por mucho tiempo la filosofía en México ha sido enseñada, en los niveles de bachillerato y normal, con una orientación predominantemente neokantiana. Sólo en los últimos años este campo ha venido a ser disputado por el neotomismo y, más recientemente, por el marxismo" (p. 260). "La filosofía en México entre 1950 y 1975, primera parte", en Las humanidades en México: 1950-1975, Coordinación de Humanidades, UNAM, México, 1975. Salmerón parece lamentarse de que la lógica no se haya enseñado en el nivel bachillerato con una tendencia analítica. Sin embargo, esta ausencia es muy poco sorprendente dado que, a diferencia de los positivistas (recordemos la Lógica de Parra), los neokantianos, los marxistas y los neotomistas, los analíticos mexicanos no han publicado - hasta la fecha- un solo libro de texto para la materia de Lógica en el bachillerato (y ni siquiera uno para la enseñanza de la lógica en un nivel superior).

31 La lógica de las ciencias fue quizá el libro de texto de lógica de mayor importancia en México hasta la publicación de La ciencia de la lógica de Eli de Gortari (Ediciones de la Universidad Michoacana, Morelia, Michoacán, 1950). Para el marxista de Gortari -como para Larroyo- la lógica es el estudio de las estructuras del conocimiento y los métodos de la ciencias (de Gortari cita en ocasiones a Natorp). Pero a diferencia de Larroyo, de Gortari considera que la lógica ha de formar parte de una teoría marxista de la dialéctica. 
científico, tales como el juicio, la conceptuación, la interrogación y la inferencia. La segunda parte, denominada teorética sintética, se ocupa de la estructura de las ciencias particulares; en esta parte, Larroyo dedica un capítulo a la teorética general que se ocupa de la elucidación de conceptos como ley, axioma, hipótesis, prueba, etc. Luego, dedica un capítulo a lo que llama teorética especial en donde ofrece una clasificación de las ciencias y dedica apartados a la lógica de la física, la química, la biología, la sociología, la historia, el derecho, la psicología, la economía e incluso la geografía.

No voy a hacer aquí un examen detallado de las diversas tesis que defiende Larroyo en este libro. Lo que haré, en cambio, es señalar algunas características del libro que, me parecen, ejemplifican el modo peculiar de hacer filosofía que Larroyo desarrolló en este libro y posteriormente en la mayoría de sus obras.

Larroyo hizo varios cambios a La lógica de las ciencias a lo largo de las sucesivas reediciones. Estos cambios pretendían actualizar el libro sin alterar la concepción original de la lógica y de la filosofía que se defendían en la primera edición. Sin embargo, en estos cambios, así como en el texto original, pueden encontrarse lo que, en mi opinión, son dos defectos del quehacer filosófico de Larroyo que se irían acentuando con los años. El primero de ellos es una tendencia cada vez más marcada hacia una especie de enciclopedismo mal llevado a cabo. Da la impresión de que Larroyo quería opinar sobre todos los temas imaginables. Si uno examina la lista de sus publicaciones uno no puede dejar de quedar asombrado al comprobar que escribió libros enteros sobre temas tan diversos como la filosofía de las matemáticas, la filosofía de la cultura, estética, psicología, pedagogía, ética, antropología, el espiritualismo, el existencialismo, el positivismo lógico, la filosofía en Norteamérica, etc., sin olvidar una historia de la filosofía de 600 páginas y una historia de la pedagogía de 800 páginas. El problema no está en la abundancia de temas —es admirable la capacidad que tenía Larroyo para estar al día en tantos asuntos y para sintetizar de manera ordenada sus lecturas - sino en el poco cuidado con el que los trataba. Y este descuido contrastaba dramáticamente con la concepción de la filosofía que pregonaba, a saber, una filosofía rigurosa y, supuestamente, atenta al detalle. Larroyo pretendía exponer una doctrina filosófica en dos páginas y refutarla de manera predecible en un párrafo. Sin duda, esta debilidad le ganó pocos adeptos entre los mejores filósofos mexicanos y también fue una de las causas por las cuales el neokantismo haya tenido un impacto casi nulo en el desarrollo de la filosofía o de la cultura en México - a pesar de que tantos preparatorianos mexicanos hayan estudiado con los libros de texto de Larroyo. Los libros de texto de Larroyo eran resúmenes de doctrinas en las que unas se refutaban y otras se defendían, pero, como bien dice Abelardo 
Villegas, "las diferencias de estas posiciones escapaban a las mentes de los preparatorianos, afanadas en entender algo". 32

La segunda debilidad que encuentro en La lógica de las ciencias y, en general, en la filosofía de Larroyo, es la obstinación casi dogmática con la que defiende casi al pie de la letra las posturas neokantianas que abrazara en su temprana juventud. Cuando Larroyo considera ideas nuevas parece que de antemano ya sabe que van a estar equivocadas si se alejan del neokantismo. De modo que muchas de las supuestas actualizaciones de $\mathrm{La}$ lógica de las ciencias no son, en el fondo, más que reiteraciones predecibles de las tesis centrales del libro. No se le podía pedir, por supuesto, que dejara de ser neokantiano, pero sí al menos, en un lapso de casi cuatro décadas, un poco de autocrítica o siquiera de duda con respecto a las tesis centrales de una filosofía que en su nombre - "filosofía crítica"- lleva el signo del antidogmatismo.

\section{El neokantismo frente a sus contrincantes}

¿Por qué el orteguismo y el existencialismo tuvieron mejor fortuna que el neokantismo en México?

Una respuesta a la pregunta que nos hemos planteado podría consistir meramente en ese afán de los filósofos mexicanos - y, en general, de los iberoamericanos, incluidos los españoles- por buscar siempre lo más nuevo en el mercado de las ideas. Pero si bien hay más de un grano de verdad en esta respuesta, creo que hay condiciones endógenas que favorecieron la recepción de estas doctrinas. Podría suponerse que el neokantismo estaba condenado a la marginalidad ya que las posiciones de poder de la filosofía en México estaban en manos de filósofos con posturas antagónicas. Me parece que esta explicación podría tener algún valor en el caso del periodo que hemos considerado - cuando Larroyo y Rodríguez eran apenas un par de jóvenes discípulos de Caso y Larroyo, y éste ni siquiera era catedrático de la Facultad de Filosofía y Letras, sino profesor de la Normal de Maestros. Pero más adelante no puede sostenerse, ya que Larroyo llegó a ser director de la Facultad de Filosofía y Letras de la unam e, incluso, Presidente de la Federación Internacional de Sociedades de Filosofía. Si su neokantismo no dejó una huella más profunda en esos años, en los que más bien tuvo su ocaso, fue por otras causas.

Se podría decir que la razón por la cual el neokantismo no tuvo el hondo impacto del orteguismo y el existencialismo en México es que estas doctrinas ofrecieron elementos conceptuales que los filósofos mexicanos de mediados

32 Abelardo Villegas, El pensamiento mexicano en el siglo xx, Fondo de Cultura Económica, México, 1993, p. 202. 
del siglo xx utilizaron para dar un nuevo giro y, quizá una conclusión, a un tema -o quizá mejor dicho, a una preocupación- que había estado presente en la conciencia mexicana desde, al menos, el siglo xviI. Me refiero a la cuestión de qué es lo mexicano y cuál es su lugar y su valor con respecto a lo europeo. La llamada filosofía de lo mexicano pudo realizarse gracias a una aplicación original de los conceptos centrales del orteguismo y el existencialismo. ${ }^{33}$

Vistas así las cosas, resulta fácil calificar el neokantismo mexicano como un movimiento reaccionario. ¿Pero ha de condenársele por ello? Ortega decía que para salir del kantismo había que entrar antes a él. Pero los filósofos mexicanos que veían el neokantismo como algo superado, no habían salido de él, i.e., no se habían formado en él. Lo que se reprochaba a los neokantianos mexicanos era que el momento histórico de su filosofía estuviera equivocado, i.e., su anacronismo (para ilustrar esto se suele contar que cuando Cassirer visitó México en los años cincuenta quedó asombrado de que aquí todavía hubiera neokantianos). Pero ¿qué valor hemos de darle a la noción del momento histórico de una filosofía? ¿No podría decirse que el momento histórico del neokantismo en México era precisamente aquél, aunque fuera distinto de su momento histórico en otros países? (L̦a filosofía analítica, por ejemplo, llegó a México varias décadas después de que naciera) ¿O hay un momento histórico para cualquier filosofía en cualquier lugar del mundo? Éstas son preguntas difíciles. Pero pienso que no hace falta responderlas para constatar que el orteguismo y el existencialismo, a diferencia del neokantismo, eran doctrinas que resultaban más útiles para los intereses concretos de muchos pensadores mexicanos de aquella época. Ahora bien, hay que señalar que el que esto fuera así, no implica que fuera lo mejor. Porque también podemos plantearnos la pregunta - tantas veces diferida o ignorada por el grueso de nuestros historiadores de la filosofíade cuáles fueron los aspectos negativos del orteguismo y del existencialismo en México. Algunos de ellos fueron vistos por Larroyo y sus seguidores y no por aquellos que estaban demasiado inmersos en lo que creían era su momento histórico. Por otra parte, sería injusto olvidar o menospreciar el esfuerzo de los neokantianos por dar a conocer las obras y el pensamiento de los principales filósofos de esta escuela a través de sus publicaciones, sus traducciones e, incluso, sus polémicas —que, a veces, son la única manera de hacerse escuchar en un medio como el nuestro. Yo me pregunto de qué manera se hubiera entendido en México a filósofos del valor como Scheler o Hartmann sin conocer, aunque fuera superficialmente, el antecedente del neokantismo; y qué decir de filósofos de la cultura como Cassirer —alumno

33 Me he ocupado con amplitud de este movimiento en: "Dos mitos de la mexicanidad", Diánoia, no. 40, Fondo de Cultura Económica, México, 1994. 
de Marburgo- o Dilthey. Acaso llegaron tarde los neokantianos a nuestro país, pero a veces se justifica el dicho de que "más vale tarde que nunca". Pero más allá de estas cuestiones, si regresamos a las críticas, creo que la crítica más sólida y más justa al neokantismo mexicano es que fue una filosofía que, por lo general (aunque con ciertas excepciones), carecía de suficiente rigor y originalidad. $Y$ es que hubo y sigue habiendo otras críticas - hechas desde el bando de los historicistas- que pierden de vista lo anterior.

En "El neokantismo ante la tradición filosófica mexicana" de 1948, Juan Hernández Luna compara el neokantismo mexicano con el positivismo y el marxismo que le precedieron. Estas corrientes -denuncia Hernández Luna- no sólo intervinieron en las directrices de la educación oficial, sino que recibieron subsidios del Gobierno. Las tres tienen también en común su desdén de la metafísica y su exaltación de la ciencia, aunque el positivismo y el marxismo antecedieron en esto a los neokantianos. Pero una diferencia entre ellas es que si bien los positivistas y marxistas habían ofrecido una interpretación de la historia de México, el neokantismo no había intentado lo mismo. Y es que - añade Hernández Luna- el neokantismo mexicano ni siquiera recordaba la tradición kantiana mexicana que inicia en el siglo xix y se preserva, de algún modo, en la obra de los ateneístas. Y si ignoran todo esto - pregunta Hernández Luna- ¿cómo pueden llamarse neokantianos de México? La respuesta que ofrece es la siguiente:

Es posible que merezcan el título de neokantianos [...], pero en todo caso no hacen honor a lo "de México", toda vez que no han sabido articular su movimiento con la tradición de un siglo de filosofía crítica que circula por el corazón de la cultura patria. (p. 299)

Esta descalificación nacionalista es muy severa, pero hay que reconocer que la mayoría de las corrientes filosóficas que se han cultivado en México han sido más bien sordas a los latidos del corazón de la cultura patria. Por otra parte, la acusación de que los neokantianos (como los positivistas y los marxistas) habían recibido los favores del erario público también es digna de consideración; pero dudo de que los detractores del neokantismo o del marxismo se encontraran -o se encuentren - libres de la misma culpa. La pregunta que hay que plantear es la de si los neokantianos mexicanos hacían buena filosofía neokantiana. Hacer esta pregunta es lo que me parece que hubiera sido en verdad saludable para la cultura nacional. ${ }^{34}$

34 Ha habido en México en los últimos años un florecimiento de estudios serios sobre la filosofía de Kant que nada tiene que ver con Larroyo ni con el neokantismo. En la Universidad Autónoma Metropolitana, la doctora Dulce María Granja encabeza un Centro de Documentación Kantiana. En la Facultad de Filosofía y Letras de la UNAM, Fernando Salmerón dirigió durante los últimos años de su vida un seminario sobre Kant, al que asistieron, entre otros, 
Es posible que las críticas de Hernández Luna al neokantismo hayan sido una reacción a un diálogo entre Juan Manuel Terán y Leopoldo Zea publicado un año antes (1947). ${ }^{35}$ Terán sostiene allí que los neokantianos mexicanos no sólo veían en la filosofía crítica la mejor arma para combatir el irracionalismo y el escolasticismo -que, según ellos, habían sido nefastos en la historia de México- sino que también pensaban que era "uno de los mejores instrumentos que se puede ofrecer para acabar con esa mentalidad colonial que nos ha caracterizado a los americanos" (p. 145). A la pregunta de Zea de cuál sería la dirección que habría de tomar una filosofía crítica americana Terán responde así:

El de lo trascendental y universal, tan ansiosamente buscado por la mentalidad europea. Nosotros los americanos estamos mejor capacitados humanamente que Europa para alcanzar este sentido de universalidad: nuestro mestizaje y el pensamiento que él implica hará posible la unidad de que carece Europa. (p. 145)

Como es previsible, Zea le responde que si hay una doctrina que justifique ese afán de pensar por cuenta propio es el historicismo. La respuesta de Terán es la siguiente:

Sí Zea, pero es aquí donde no podemos estar de acuerdo. El historicismo es entre otras cosas una expresión más de ese mundo dividido llamado Europa. [...] Es la expresión de todos esos nacionalismos que la dividen. En cambio, América es la expresión de todo lo contrario; de aquí que el historicismo sea peligroso para fundamentar una filosofía americana. Tal filosofía sobrevaloraría las condiciones peculiares de nuestro continente, se tornaría en un ismo más. (p. 145)

Más allá de la afirmación profética de Terán acerca del latinoamericanismo que luego cultivaran Zea y otros, es interesante percatarse de que los neokantianos no se sustraen a la cuestión de si puede haber una filosofía americana y cómo ha de ser ésta. Es más, también piensan, como Zea y los filosófos de lo mexicano, que estando la vieja Europa en ruinas —en todos los sentidos- América y en especial México, son los únicos lugares en donde se dan las condiciones para alcanzar el avance del espíritu. Pero a diferencia de Zea y los filósofos de lo mexicano, los neokantianos piensan que la filosofía americana no tiene temas propios. Al contrario, piensan que

los ahora profesores Julio Beltrán y Efraín Lazos. En el Instituto de Investigaciones Filosóficas de la unAM, los doctores Carlos Pereda, Pedro Stepanenko e Isabel Cabrera han hecho valiosas investigaciones sobre la epistemología y la metafísica kantianas.

35 Leopoldo Zea, "Significación del neokantismo mexicano: diálogo con Juan Manuel Terán", Filosofía y Letras, no. 25, enero-marzo, 1947. 
a diferencia de Europa -en donde los ismos provocaron la destrucciónen América se ha de cultivar la verdadera filosofía universal.

Antes de acabar quisiera comparar la postura de los neokantianos con la de los analíticos. Aunque desde principios de la década de los cincuenta empezaron a circular en México las ideas de Russell, Carnap y Ayer (entre otros), ${ }^{36}$ podemos decir que el evento fundacional de la filosofía analítica mexicana fue el lanzamiento de Crítica en 1967. En la presentación de esta revista, los editores - Alejandro Rossi, Fernando Salmerón y Luis Villoroafirmaron estar en contra de la "especulación metafísica", de las "filosofías de la Weltanschaung" (término que, como se recordará, Larroyo también usaba de manera despectiva), del "afán de ofrecer sistemas personales del mundo" y de "las reflexiones - más o menos literarias- acerca de las características culturales o sociológicas de los países" -en otras palabras, la filosofía de lo mexicano, para entonces ya caduca, y la filosofía latinoamericana, todavía pujante en aquellos años. Como se verá, los oponentes declarados de los analíticos en 1967 eran los mismos que había combatido Larroyo. Sin embargo, no hubo colaboración entre los neokantianos y los analíticos. Y es que, entre otras razones, Crítica fue iniciada por un pequeño grupo de exalumnos de Gaos que veían a Larroyo con recelo e incluso, yo diría, con desprecio.

Sin embargo, puedo imaginarme que Larroyo haya encontrado cierta ironía e incluso cierta vindicación en el hecho de que algunos alumnos de Gaos y Zea - sus viejos enemigos filosóficos- se cambiaran a un bando, que si bien no era el suyo, era cercano. Y es que entre la filosofía analítica y el neokantismo hay muchas diferencias, pero también hay muchas semejanzas. Los primeros analíticos mexicanos defendieron una concepción de la filosofía como una disciplina rigurosa, técnica, cercana a las ciencias y alejada de la metafísica tradicional, semejante a la que Larroyo había enarbolado desde 1936. Pero aunque los analíticos mexicanos respetaban el viejo neokantismo alemán, menospreciaban el mexicano. En una conferencia que dio en 1967, Alejandro Rossi, afirmaba que "más allá de los logros filosóficos no siempre claros y a veces sumamente dudosos, cuando no deleznables" del neokantismo mexicano, si éste y el positivismo hubieran tenido éxito histórico en nuestro país, la filosofía mexicana hubiera tenido mejor nivel, hubiera sido más técnica, más consciente de su lugar en relación con otras disciplinas. ${ }^{37}$

36 En La filosofía iberoamericana (Porrúa, 1978, p. 173), Larroyo hace una curiosa reseña de una mesa redonda que se llevó a cabo en 1968 en tomo a la filosofía analítica, en la que participaron González Uribe, Recaséns Siches, Sánchez Vázquez, Molina Flores y el propio Larroyo.

37 Alejandro Rossi, "El sentido actual de la filosofía en México", Revista de la Universidad de México, vol. XXII, no. 5, enero 1968, pp. I-VIII. 
También había afinidades entre la concepción de la educación que tenían los analíticos y los neokantianos. Los primeros analíticos mexicanos, como antes los neokantianos y los positivistas del siglo xIx, pensaban que había que enseñar a los mexicanos - proclives a la divagación y a la ensoñacióna respetar, primero, y emular, después, el rigor y la exactitud del discurso científico. Si subrayamos las semejanzas en vez de las diferencias, se puede decir que la filosofía analítica se inscribe en una persistente tendencia antimetafísica y procientífica de nuestro pensamiento que se remonta, por lo menos, hasta el positivismo del siglo xix y en donde también se inscribe - no hay que olvidarlo- el marxismo cultivado por Vicente Lombardo Toledano y Eli de Gortari, entre otros. ${ }^{38}$ Una apostilla: he dicho que la filosofía analítica mexicana se inscribe en una tendencia antimetafísica y procientífica, pero sería un grave error sostener que todos los analíticos mexicanos han sido antimetafísicos o procientíficos — de hecho, algunas de las contribuciones más importantes de los analíticos mexicanos han sido en el área de la metafísica. Hoy en día son pocos los analíticos que piensan que la ciencia es el paradigma del conocimiento o que la metafísica carece de problemas genuinos. (Aunque cabe señalar que hay actualmente un grupo de epistemólogos y filósofos de la ciencia mexicanos que defienden nuevas versiones de la doctrina de que la realidad depende de nuestros conceptos. A este kantismo que ha florecido recientemente en la filosofía analítica se le denomina, entre otras maneras, realismo interno. ${ }^{39}$

En los últimos años de su vida Larroyo se interesó por la filosofía analítica:- Sin embargo, el conocimiento que adquirió de ella fue superficial y las críticas que le lanzó partían, en no pocas ocasiones, de malentendidos muy elementales. Larroyo advirtió que en la filosofía analítica hallaba una aliada en su lucha en contra de la metafísica, pero no pudo dejar de verla a través de los lentes opacos del neokantismo decimonónico. En La lógica de la ciencias, por ejemplo, fue añadiendo en las sucesivas reediciones secciones en las que daba a conocer algunos autores y doctrinas de esta escuela e incluso se ofrecían algunos elementos - muy rudimentarios- de lógica matemática. Pero la exposición que hace de la filosofía analítica es

38 La inclusión del marxismo, i.e., del socialismo científico, en la tradición cientificista de la filosofía mexicana tiende a olvidarse en algunos autores. Tal es el caso de Villegas en $E l$ pensamiento mexicano en el siglo $\mathrm{xx}$, que se obstina en presentar a los positivistas, neokantianos y analíticos en el mismo rubro de cientificistas y de caricaturizarlos como intelectuales alejados de la realidad nacional.

39 En Diánoia 1992 aparecen ensayos de algunos filósofos analíticos mexicanos que han examinado esta doctrina. Entre los defensores de alguna versión del realismo interno se encuentran: Sergio Martínez, Ana Rosa Pérez y León Olivé. Entre sus atacantes contamos a: Mauricio Beuchot, Adolfo García de la Sienra y quien escribe esto. Yo me he vuelto a ocupar de esta cuestión en "Realismo, relativismo e irrealismo", Crítica, no. 90, diciembre de 1998. 
muy deficiente. Para ponerlo en pocas palabras: no entendió de qué trataba la filosofía analítica. En 1968 Larroyo publicó El positivismo lógico: pro y contra. Aunque la obra padecía de los mismos defectos de las demás obras de Larroyo, se trataba del primer libro sobre la filosofía analítica escrito por un filósofo mexicano. No obstante, los analíticos mexicanos ignoraron el libro. En ese mismo año, el joven Hugo Margáin había publicado en Crítica una reseña de apenas un par de páginas en donde se burlaba de los errores lógicos que cometía Larroyo en La lógica de las ciencias. El inicio de la reseña de Margáin ilustra el desprecio que sentían los analíticos por la obra de Larroyo. Decía Margáin:

No merecería este libro comentario alguno si no fuese uno de los textos más usados en México y si no estuviese mencionado en el programa de Lógica de la Escuela Nacional Preparatoria: señalar sus errores, indicar la pobreza o miopía de sus observaciones, no es empeño que en sí mismo deba interesar a nadie. Sirvan estas observaciones para señalar las bondades de la enseñanza de la lógica en nuestra educación media. ${ }^{40}$

Pero más allá de los errores que pudiesen encontrarse en las obras de Larroyo, me parece que los analíticos mexicanos de aquellos años pensaban que tanto Larroyo, como De Gortari e incluso García Máynez —ejemplo, entonces y hoy, de un filósofo riguroso y original- pertenecían a un momento superado del desarrollo de las ideas; i.e., que eran, como hubiera dicho Larroyo, epígonos de filosofías superadas. Para los analíticos no eran tiempos, los suyos, para el diálogo, ni para la memoria, sino para aprender y, luego, para construir algo digno sobre lo que ellos veían como un páramo. A más de treinta años del arribo a México de la filosofía analítica, es tiempo ya de juzgar si los analíticos triunfaron ahí donde los neokantianos fracasaron. Pero esta es una cuestión que no podemos plantearnos aquí.

40 Hugo Margáin, "Reseña de La lógica de las ciencias", Crítica, vol. II, no. 5, mayo 19.68, p. 116. 